\title{
Uji Klinis Tersamar Acak Ganda Pemberian Parasetamol Pasca Imunisasi DTwP-Hep B-HIB
}

\author{
Abdullah Reza, Teny Tjitra Sari, Hindra Irawan Satari, Soedjatmiko, Kemas Firman \\ Departemen Ilmu Kesehatan Anak Fakultas Kedokteran Universitas Indonesia/RS Cipto Mangunkusumo
}

\begin{abstract}
Latar belakang. Demam, pengurangan waktu tidur, nyeri, dan reaksi lokal adalah beberapa kejadian ikutan pasca imunisasi. Untuk mencegah hal tersebut, profilaksis parasetamol pasca imunisasi diberikan oleh tenaga medis maupun orang tua. Peraturam Menteri Kesehatan Republik Indonesia dan Pedoman Imunisasi IDAI belum menetapkan secara tegas boleh atau tidaknya pemberian profilaksis parasetamol pasca imunisasi.
\end{abstract}

Tujuan. Mengetahui efektivitas pemberian profilaksis parasetamol oral untuk mencegah kejadian ikutan pasca imunisasi kombinasi DTwP-Hep B-Hib.

Metode. Uji klinis tersamar acak ganda (double blind randomized control triall) dengan pemberian parasetamol dan plasebo pada pasien pasca imunisasi kombinasi DTwP-Hep B-Hib di Puskesmas Kecamatan Kramat Jati dan Kelurahan Batu Ampar selama September 2015 sampai Oktober 2015. Satu hari pasca imunisasi, kelompok perlakuan diberikan parasetamol (40-50 mg/kgBB/hari) yang terbagi empat dosis, sedangkan kelompok kontrol mendapatkan plasebo. Selama empat hari pasca imunisasi dilakukan pengukuran suhu aksila, lama tidur, dan reaksi inflamasi lokal.

Hasil. Subjek terdiri atas 100 bayi yang mendapatkan imunisasi kombinasi DTwP-Hep B-Hib ketiga. Karakteristik dasar meliputi usia, jenis kelamin, dan status gizi tidak berbeda di kedua kelompok. Subjek penelitian mendapatkan profilaksis parasetamol ( 50 subjek) dan profilaksis plasebo (50 subjek). Seluruh subjek penelitian tidak demam, tidak mengalami gangguan tidur, dan tidak ditemukan reaksi lokal. Pemberian parasetamol 24 jam pasca imunisasi DTwP-Hep B-Hib menunjukkan penurunan suhu $0,1^{\circ} \mathrm{C}-0,2^{\circ} \mathrm{C}$ yang bermakna secara statistik $(\mathrm{p}<0,05)$ pada 24 jam pertama pasca imunisasi. Pemberian parasetamol menunjukkan waktu tidur yang lebih lama, tetapi tidak bermakna secara statistik $(\mathrm{p}>0,05)$ pada lama tidur.

Kesimpulan. Pemberian parasetamol profilaksis pasca imunisasi DTwP-Hep B-Hib selama satu hari dapat menurunkan suhu tubuh pada 24 jam pasca imunisasi. Sari Pediatri 2017;19(1):20-4

Kata kunci: imunisasi, parasetamol, demam, reaksi lokal, waktu tidur

\section{Effect of Prophylactic Paracetamol Administration at Time of DTwP-Hep B-Hib Immunization: Double Blind, Randomized Clinical Controlled Trial}

\author{
Abdullah Reza, Teny Tjitra Sari, Hindra Irawan Satari, Soedjatmiko, Kemas Firman
}

Background. Fever, decreased sleep time, pain and local reaction are adverse event following vaccination especially DTwP vaccine. Parent and medical staff almost give paracetamol prophylactic to reduce adverse event after vaccinantion. Peraturam Menteri Kesehatan Republik Indonesia (Ministry of Health Republic of Indonesia Health Law) and Pedoman Imunisasi IDAI (Indonesia Pediatric Society Immunization Guideline) never explicitly allowed prophylactic paracetamol administration post immunization.

Objective. To assess the efficacy of prophylactic paracetamol administration compared with placebo for prevent adverse event after immunization.

Method. A randomized double-blind clinical trials by administering paracetamol and placebo post-immunization DTwP - Hep B $\mathrm{Hib}$ in Kramat Jati district primary health care and Batu Ampar sub-distric primary health care during September to October 2015. One day after vaccination, the treatment group was given paracetamol ( $40-50 \mathrm{mg} / \mathrm{kg} / \mathrm{day})$, divided into 4 doses, while the control group was given placebo. Axillary temperature, time of sleep, and local reactions was evaluated until 4 day after vaccination.

Result. Subjects of this study consisted of 100 infants (50 paracetamol \& 50 placebo) after DTwP-Hep B-Hib third primary immunization. The baseline characteristic including age, gender, and nutritional status were similar in both groups. All subject showed no fever, no local reaction, neither nor sleep disturbance. Prophylactic paracetamol 24 hours post DTwP-Hep B-Hib immunization showed decreased temperature of $0.1^{\circ} \mathrm{C}-0.2^{\circ} \mathrm{C}(\mathrm{p}<0.05)$ in the first 24 hours post- immunization. Administration of paracetamol showed longer sleep time ( $\mathrm{p}>0.05$ ) in the first 24 hours post- immunization.

Conclusion. Prophylactic administration of paracetamol post DTwP-Hep B-Hib immunization during the day can lower body temperature at 24 hours post- immunization. Sari Pediatri 2017;19(1):20-4

Keywords: immunization, paracetamol, fecer, local reaction, sleep time

Alamat korespondensi: DR. Dr. Teny Tjitra Sari, SpA(K), Dr. Abdullah Reza. Departemen Ilmu Kesehatan Anak Fakultas Kedokteran Universitas Indonesia/RS Cipto Mangunkusumo. E-mail: abdullah_reza@yahoo.com 
$\mathrm{P}$ eningkatan angka cakupan imunisasi akan diikuti dengan peningkatan angka pelaporan Kejadian Ikutan Pasca Imunisasi (KIPI) yang merupakan sisi lain dari program imunisasi. Begitu pula dengan imunisasi kombinasi DTwP-Hep B-Hib yang umumnya menimbulkan KIPI berupa demam, reaksi inflamasi lokal, dan pengurangan waktu tidur. ${ }^{1,2,3}$

Demam merupakan respon yang normal dari proses inflamasi yang biasanya disebabkan oleh infeksi. Proses demam berdampak baik untuk meningkatkan daya tahan tubuh dalam melawan suatu infeksi dan membentuk antibodi. Demam dapat ditemukan setelah dilakukan imunisasi. ${ }^{4}$ Umumnya, terdapat keterlibatan zat pirogenik endogen, terutama interleukin 1 dan tumor necrosis factor $\alpha$ dan berkaitan dengan peningkatan aktivitas sel $\mathrm{T}$ dalam mendeteksi antigen dan menimbulkan respon imun. ${ }^{5}$

Demam dan reaksi lokal pasca imunisasi umumnya ringan dan dapat sembuh tanpa pengobatan. ${ }^{6}$ Namun, orang tua dan tenaga medis memberi perhatian khusus karena khawatir terjadinya efek samping yang berlebihan akan menimbulkan kelainan patologi yang menetap. ${ }^{7,8}$ Dengan demikian, pemberian antipiretik profilaksis umumnya sering diberikan pasca imunisasi DPT whole cell (DTwP) atau imunisasi lainnya., ${ }^{9,10}$

Survey tahun 2010 terhadap orang tua bayi yang mendapatkan imunisasi menunjukkan bahwa 90\% khawatir terjadi demam pasca imunisasi DTwP dan meminta tim medis secara rutin memberikan obat demam pada hari pertama pasca imunisasi. Survey tahun 2011 dan 2012 terhadap tenaga medis yang memberikan imunisasi DTwP menunjukkan bahwa $90 \%$ bidan dan perawat, serta $70 \%$ dokter spesialis anak memberikan profilaksis parasetamol, sedangkan $80 \%$ dokter umum memberikan parasetamol ${ }^{11}$

Peraturan menteri Kesehatan Republik Indonesia dan Pedoman Imunisasi IDAI belum secara eksplisit mengatur pemberian profilaksis parasetamol pasca imunisasi. Hal tersebut dikarenakan basis bukti yang baik mengenai efektivitas profilaksis parasetamol dalam mengurangi KIPI belum didapatkan. ${ }^{1,12}$ Oleh karena itu, penelitian ini berusaha melihat efektivitas parasetamol dalam mencegah KIPI.

Tujuan penelitian ini untuk mengetahui efektivitas pemberian profilaksis parasetamol oral untuk mencegah kejadian ikutan pasca imunisasi kombinasi DPwTHep B-Hib (mengurangi demam, mengurangi reaksi inflamasi lokal dan meningkatkan lama tidur).

\section{Metode}

Desain penelitian digunakan adalah uji klinis tersamar acak ganda (double blind randomized clinical trial). Penelitian dilakukan di Puskesmas kecamatan Kramat Jati dan kelurahan Batu Ampar. Penelitian dilaksanakan pada bulan September - Oktober 2015. Populasi target penelitian adalah bayi sehat usia di atas dua bulan yang mendapatkan imunisasi kombinasi DPwT-Hep B-Hib $\left(\right.$ Pentabio $\left.^{\oplus}\right)$.

Kriteria inklusi terdiri atas bayi sehat laki-laki atau perempuan usia di atas dua bulan dan orang tua atau wali subjek mengerti serta bersedia mengikuti penelitian. Kriteria eksklusi terdiri atas subjek dengan riwayat lahir prematur (kurang dari 37 minggu), dengan riwayat berat lahir rendah (kurang dari 2000 $\mathrm{g})$, telah minum antipiretik dalam 6 jam sebelum imunisasi, suhu tubuh awal $40^{\circ} \mathrm{C}$, terdapat riwayat kejadian simpang pasca pemberian parasetamol, dalam terapi pengobatan untuk penyakit akut dan kronik, dan dengan status gizi buruk.

Alokasi subyek ke dalam kelompok penelitian dilakukan secara random dengan menggunakan blok randomisasi dengan dua blok. Pemilihan subyek penelitian dilakukan dengan cara consecutive sampling. Parasetamol (yang digunakan dalam penelitian ini adalah sanmol ${ }^{\oplus}$ Drop) merupakan obat antipiretik dan analgesik yang disediakan dalam bentuk drops dengan konsentrasi $100 \mathrm{mg} / \mathrm{mL}$. Plasebo merupakan sirupus dengan warna dan rasa yang sama dengan parasetamol.

Pemeriksaan suhu berkala (setiap 4 jam selama 4 hari pasca imunisasi) yang dilakukan oleh orang tua adalah pemeriksaan suhu aksila dengan termometer digital terkalibrasi (Magic Star'). Demam didefinisikan sebagai suhu tubuh aksila lebih dari $38^{\circ} \mathrm{C}$. Reaksi lokal adalah reaksi baik indurasi atau eritema pada lokasi suntikan imunisasi, pengukuran dilakukan oleh peneliti utama dengan penggaris terkalibrasi (Butterfly") dan dinyatakan dalam satuan milimeter. Lama tidur diukur dengan menjumlahkan lama tidur selama 24 jam, sampai dengan empat hari pasca imunisasi, pencatatan dilakukan oleh orang tua.

Subjek penelitian dilakukan penyuntikan imunisasi kombinasi DTwP-Hep B-Hib (Pentabio ${ }^{\circ}$ ) 0,5 mL menggunakan syringe $1 \mathrm{~mL}$ dan Jarum $25 \mathrm{G}$ (panjang $25 \mathrm{~mm}$ ) secara intramuskular pada otot vastus lateralis kanan. Dosis pertama diberikan langsung oleh peneliti pasca imunisasi dengan jumlah $0,1 \mathrm{~mL}$ per kilogram berat badan. Dosis obat kedua, ketiga, dan keempat 
diberikan mandiri oleh orangtua/wali di rumah dengan volume pemberian dan waktu pemberian selama $1 \mathrm{x}$ 24 jam dan pengawasan selama 4 hari.

Data diolah dengan program SPSS 22. Hasil analisis penelitian disajikan dalam bentuk teks dan tabular. Penelitian ini telah mendapatkan persetujuan dari Komite Etik Penelitian Fakultas Kedokteran Universitas Indonesia pada tanggal 13 Juli 2015 dengan surat lulus kaji etik nomor 581/UN2.F1/ETIK/2015).

\section{Hasil}

Total subjek yang mengikuti penelitian secara lengkap adalah 100 bayi dengan rentang usia seluruhnya adalah $4,1 \pm 0,2$ bulan. Rasio bayi lelaki dengan perempuan sebanding pada kedua kelompok. Sebagian besar subjek memiliki status gizi baik dan tidak ada yang memiliki status gizi lebih atau obesitas. Sebagian subjek tidak memiliki riwayat KIPI pada imunisasi pertama dan kedua, tetapi tidak secara spesifik ditanyakan jenis dari KIPI yang dialami sebelumnya.

Tidak ditemukan subjek dengan kondisi demam, baik pada pemberian parasetamol maupun plasebo. Uji normalitas data Kolmogorov-Smirnov menunjukkan bahwa seluruh data suhu pada pemberian parasetamol maupun plasebo memiliki sebaran yang normal. Oleh karena itu, dilakukan uji $\mathrm{T}$ tidak berpasangan pada seluruh data suhu pada pemberian parasetamol dan plasebo. Perbedaan suhu pasca imunisasi pada pemberian parasetamol $(\mathrm{p}<0,05)$ pada 24 jam pertama dengan nilai perbedaan suhu berkisar antara $0,1-0,2$ ${ }^{\circ} \mathrm{C}$ (Gambar 1 dan Tabel 1).

Reaksi lokal, baik berupa indurasi atau eritema, tidak dilaporkan oleh orang tua selama penelitian dan tidak ditemukan pada pemeriksaan fisis akhir penelitian (lima hari pasca imunisasi). Tidak ditemukan adanya reaksi lokal pada kedua perlakuan (parasetamol dan plasebo) sehinggga tidak dilakukan analisis statistik lanjutan.

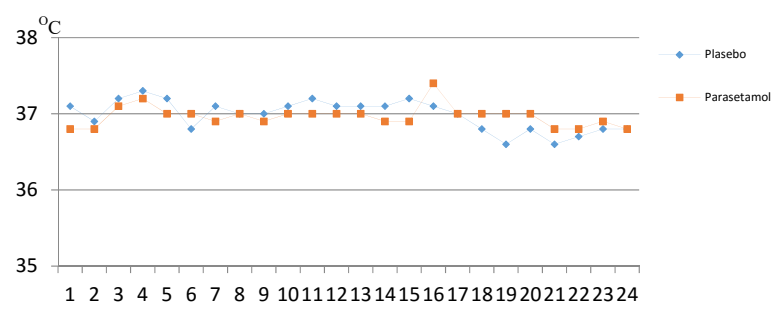

Gambar 1. Rerata suhu pengukuran per 4 jam
Tabel 1 Rerata suhu (per 4 jam)

\begin{tabular}{|c|c|c|c|}
\hline Suhu ke- & Parasetamol $(n=50)$ & Plasebo $(n=50)$ & $\mathrm{p}$ \\
\hline 1 & $36,8+0,4$ & $37,1 \pm 0,2$ & 0,00 \\
\hline 2 & $36,8+0,2$ & $36,9 \pm 0,4$ & 0,01 \\
\hline 3 & $37,1+0,2$ & $37,2 \pm 0,4$ & 0,02 \\
\hline 4 & $37,2+0,1$ & $37,3 \pm 0,3$ & 0,03 \\
\hline 5 & $37+0,2$ & $37,2 \pm 0,3$ & 0,01 \\
\hline 6 & $37+0,3$ & $36,8 \pm 0,3$ & 0,04 \\
\hline 7 & $36,9+0,2$ & $37,1 \pm 0,2$ & 0,23 \\
\hline 8 & $37+0,5$ & $37 \pm 0,1$ & 0,29 \\
\hline 9 & $36,9+0,3$ & $37 \pm 0,2$ & 0,33 \\
\hline 10 & $37+0,2$ & $37,1 \pm 0,2$ & 0,82 \\
\hline 11 & $37+0,2$ & $37,2 \pm 0,2$ & 0,14 \\
\hline 12 & $37+0,2$ & $37,1 \pm 0,1$ & 0,45 \\
\hline 13 & $37+0,4$ & $37,1 \pm 0,1$ & 0,55 \\
\hline 14 & $36,9+0,1$ & $37,1 \pm 0,2$ & 0,25 \\
\hline 15 & $36,9+0,2$ & $37,2 \pm 0,3$ & 0,26 \\
\hline 16 & $37,4+0,3$ & $37,1 \pm 0,2$ & 0,26 \\
\hline 17 & $37+0,2$ & $37 \pm 0,2$ & 0,35 \\
\hline 18 & $37+0,3$ & $36,8 \pm 0,2$ & 0,36 \\
\hline 19 & $37+0,3$ & $36,6 \pm 0,1$ & 0,38 \\
\hline 20 & $37+0,2$ & $36,8 \pm 0,3$ & 0,39 \\
\hline 21 & $36,8+0,3$ & $36,6 \pm 0,3$ & 0,50 \\
\hline 22 & $36,8+0,4$ & $36,7 \pm 0,4$ & 0,29 \\
\hline 23 & $36,9+0,2$ & $36,8 \pm 0,3$ & 0,09 \\
\hline 24 & $36,8+0,3$ & $36,8 \pm 0,3$ & 0,22 \\
\hline
\end{tabular}

Secara keseluruhan, tidak ditemukan subjek dengan kondisi gangguan tidur pada pemberian parasetamol maupun plasebo. Seluruh subjek tidur di atas delapan jam. ${ }^{31}$ Uji normalitas data KolmogorovSmirnov menunjukkan bahwa seluruh data lama tidur pada pemberian parasetamol maupun plasebo memiliki sebaran yang normal. Oleh karena itu, dilakukan uji $T$ tidak berpasangan pada seluruh data suhu pada pemberian parasetamol dan plasebo (Tabel 2).

Tabel 2. Rerata lama tidur (jam per hari)

\begin{tabular}{lccc}
\hline $\begin{array}{l}\text { Lama } \\
\text { tidur } \\
\text { hari ke- }\end{array}$ & $\begin{array}{c}\text { Parasetamol } \\
(\mathrm{n}=50)\end{array}$ & $\begin{array}{c}\text { Plasebo } \\
(\mathrm{n}=50)\end{array}$ & $\mathrm{p}$ \\
\hline 1 & $11,1 \pm 1,2$ & $10,8 \pm 1,3$ & 0,22 \\
2 & $11,8 \pm 1,2$ & $11,2 \pm 1,4$ & 0,51 \\
3 & $11,5 \pm 1,2$ & $11,4 \pm 1,2$ & 0,88 \\
4 & $10,8 \pm 1,4$ & $10,7 \pm 1,3$ & 0,43 \\
\hline
\end{tabular}




\section{Pembahasan}

Kami tidak menemukan subjek yang demam pada pemberian profilaksis parasetamol maupun plasebo. Oleh karena itu, kami tidak dapat menyimpulkan bahwa profilaksis parasetamol pasca imunisasi DTwP-Hep B-Hib dapat menurunkan angka demam pasca imuniasi. Limapuluh subjek yang diberikan profilaksis parasetamol pasca imunisasi memiliki suhu yang lebih rendah $0,1-0,2$ ${ }^{\circ} \mathrm{C}$ dibanding yang mendapatkan plasebo. Hal tersebut sesuai dengan penelitian yang dilakukan oleh Prymula $\mathrm{dkk}^{13}$ yang melaporkan bahwa pemberian profilaksis parasetamol memberikan suhu yang lebih rendah dibandingkan dengan tanpa profilaksis.

Profilaksis parasetamol memang efektif untuk mengurangi reaksi demam yang sering dijumpai setelah imunisasi dasar dan booster, tetapi demam yang bersifat ringan-sedang tersebut tidaklah menjadi pertimbangan penting. Das dkk ${ }^{14}$ melaporkan bahwa gejala lokal dan sistemik setelah imunisasi primer, bukan imunisasi sekunder berkurang. Tiga belas uji klinis $R C T$ menyimpulkan bahwa walaupun reaksi demam secara bermakna berkurang, tetapi pemberian profilaksis parasetamol saat imunisasi tidak boleh secara rutin di anjurkan karena respon antibodi terhadap beberapa antigen vaksin akan berkurang. Bagaimanapun juga, respon antibodi pada kelompok profilaksis parasetamol tidak akan turun di bawah level sero-protektif antibodi sehingga tampaknya profilaksis parasetamol tidak akan memberikan efek yang merugikan untuk kesehatan anak. Hal tersebut sesuai dengan rekomendasi praktek imunisasi yang dikeluarkan oleh Brighton Collaboration Fever Working Group. ${ }^{15}$

Kami tidak menemukan subjek yang mengalami inflamasi lokal, baik berupa indurasi atau eritema, pada pemberian profilaksis parasetamol maupun plasebo. Oleh karena itu, profilaksis parasetamol pasca imunisasi DTwP-Hep B-Hib tidak tidak dapat disimpulkan dapat menurunkan angka reaksi lokal pasca imunisasi. Jackson $\mathrm{dkk}^{16}$ melaporkan manfaat parasetamol untuk mengurangi inflamasi pasca imunisasi, walaupun tidak bermakna secara statistik. Hal tersebut sesuai dengan temuan terdahulu, seperti yang dilakukan oleh Ipp ${ }^{17}$ dan Lewis. ${ }^{18}$ Kejadian inflamasi lokal secara konsisten berhubungan dengan reaktogenisitas formula pertusis whole cell dibandingkan dengan formula pertusis aseluler. ${ }^{19}$

Reaksi inflamasi lokal antara yang diberikan parasetamol maupun plasebo tidak ditemukan.
Hal tersebut dimungkinkan karena jumlah sampel penelitian ini lebih kecil dibandingkan dengan sampel penelitian yang disebutkan di atas. Faktor vaksin dan cara penyuntikan dapat disingkirkan karena sesuai kaidah yang benar.

Kami tidak menemukan subjek yang mengalami gangguan tidur pada pemberian profilaksis parasetamol maupun plasebo karena seluruh subjek memiliki waktu tidur di atas 8 jam. Oleh karena itu, profilaksis parasetamol pasca imuniasai DTwP-Hep B-Hib tidak dapat disimpulkan dapat mengurangi gangguan tidur. Namun demikian, ditemukan perbedaan rerata lama tidur antara parasetamol dan plasebo selama 1 jam pada hari pertama, walaupun tidak bermakna secara statistik. Hal tersebut sesuai dengan sebuah RCT yang dilakukan oleh Franck $\mathrm{dkk}^{20}$ yang melaporkan tentang tidur pada bayi setelah imunisasi dan kaitannya dengan pemberian parasetamol. Studi RCT tersebut menemukan bahwa parasetamol yang diberikan setelah imunisasi (bukan sebagai profilaksis) berhubungan dengan peningkatan durasi tidur pada bayi pasca imunisasi. Pada studi di atas juga melaporkan bahwa gangguan tidur berhubungan dengan penurunan formasi antibodi pada orang dewasa dan anak pasca imunisasi dan menyimpulkan bahwa pemberian parasetamol pasca imunisasi mungkin dapat memfasilitasi respon imun. ${ }^{19}$ Namun, serupa dengan penelitian kami, studi Franck $\mathrm{dkk}^{19}$ juga tidak menunjukkan tingkat kemaknaan secara statistik.

\section{Kesimpulan}

Tidak ditemukan demam, reaksi lokal, dan ganguan tidur pasca imunisasi DTwP-Hep B-Hib pada semua subjek. Subjek yang mendapatkan profilaksis parasetamol pasca imunisasi DTwP-Hep B-Hib memiliki suhu yang lebih rendah dan waktu tidur yang lebih lama pada 24 jam pertama pasca imunisasi. Disarankan kepada IDAI dan KeMenKes, parasetamol dapat diberikan pasca imunisasi jika terdapat indikasi terapeutik bukan sebagai profilaksis.

\section{Daftar pustaka}

1. Hayat H, Khan PS, Hayat G. The effect of prophylactic paracetamol administration on adverse reactions following DTP vaccination: randomised controlled trials. Eastern J Med 2011;16:258-60. 
2. Jong DM, Suranto A, Gunardi H, Tumbelaka AR. Kejadian ikutan pasca imunisasi vaksin kombinasi DPwT (sel utuh) dan hepatitis B. Sari Pediatri 2001;3:72-6.

3. Rusmil K, Gunardi H, Fadiyana E, Soedjatmiko, Dhamayanti M, Sekartini R, dkk. The immunogenocitym safety, and concistency of an Indonesia combined DTP-HB-Hib vaccine in expanded program on immunization schedule. BMC Pediatrics 2015;15:219.

4. Tichmann-Schumann I, Soemantri P, Behre U, DisselhoffJ, Mahler $\mathrm{H}$, Maechler G, dkk. Immunogenicity and reactogenicity of four doses of diphtheria-tetanus-three-component acellular pertussishepatitis B-inactivated polio virus-Haemophilus influenzae type $b$ vaccine coadministered with 7-valent pneumococcal conjugate Vaccine. Pediatr Infect Dis J 2005;24:70-7.

5. Knuf M, Harbermehl P, Cimino C, Petersen G, Schmitt HJ. Immunogenocity, reactogenicity and safety of 7-valent pneumococcal conjugate vaccine (PCV7) concurrently administered with a DTPa-HBV-IPV/Hib combination vaccine in healthy infant. Vaccine 2006;24:4727.

6. Olivier C, Belohradsky BH, Stojanov S, Bonnet E, Petersen G, Liese JG. Immunogenocity, reactogenicity and safety of 7-valent pneumococcal conjugate vaccine (PCV7) concurrently administered with a fully liquid DTPa-IPV-HBV-Hib combination vaccine in healthy infants. Vaccine 2008;26:3142-52.

7. Jacobson RM. An update on childhood and adolescent vaccines. Mayo Clin Proc 2009;84:457-9.

8. Adam HM. Fever adn host responses. Pediatr Rev 1996;17:330-1.

9. El-Radhi AS. Why is the evidence not affecting te practice of fever management? Arch Dis Child 2008;93:918-20.

10. Grocetti M, Moghbeli N, Serwint J. Fever fobia in revisited: have parental misconceptions about fever changed in 200 years? Pediatrics 2001;107:1241-6.

11. Reza A. Survey profilaksis parasetamol pasca Imunisasi DTwP pada orangtua dan tenaga Medis (tidak publikasi). Jakarta: Universitas Indonesia; 2012.
12. Tumbelaka AR, Soedjatmiko. Tanya jawab orang tua mengenai imunisasi. Dalam: Pedoman Imunisasi di Indonesia. Edisi 5. Jakarta: Satgas Imunisasi IDAI;2014.h.404.

13. Prymula P, Siegrist CA, Chlibek R, Zemlickova H. Effect of prophylactic paracetamol administration at time of vaccination on febrile reactions and antibody responses in children: two open label, randomized controlled trials. Lancet 2009;374:1339-50.

14. Das RR, Panigrahi I, Naik SS. The effect of prophylactic antipyretic administration on post-vaccination adverse reactions and antibody response in children: a systematic review. PLos One 2014;9:e106629.

15. Kohl KS, Marcy SM, Blum M, Connell Jones M, Dagan R, Hansen J, dkk. Brighton collaboration fever working group. Fever after immunization: current concepts and improved future scientific understanding. Clin Infect Dis. 2004;39:389-94.

16. Jackson LA, Peterson D, Dunn J, Hambidge SJ, Dunstan M, Starkovich P, dkk. A randomized placebo-controlled trial of acetaminophen for prevention of post-vaccination fever in infants. PLoS One 2011;6:e20102.

17. Ipp MM, Gold R, Greenberg S, Goldbach M, Kupfert BB, Lloyd DD, dkk. Acetaminophen prophylaxis of adverse reactions following vaccination of infants with diphtheriapertussis-tetanus toxoids-polio vaccine. Pediatr Infect Dis J 1987;6:721-5.

18. Lewis K, Cherry JD, Sachs MH, Woo DB, Hamilton RC, Tarle JM, dkk. The effect of prophylactic acetaminophen administration on reactions to DTP vaccination. Am J Dis Child 1988;142:62-5.

19. Huang WT, Gargiullo PM, Broder KR, weintraub ES, Iskander $\mathrm{JK}$, dkk. Lack of association between acellular pertusis vaccine and seizures in early childhood. Pediatrics 2010;126:263.

20. Franck L, Gay CL, Lynch M, Lee KA. Infant sleep after immunization: randomized controlled trial of prophylactic acetaminophen. Pediatrics 2011;128:1100-8. 